\title{
DIREITO E AMOR
}

\author{
Humberto Grande \\ Professor da Faculdade de Direito da Universida- \\ de do Paraná
}

A compreensão do direito deve começar pelo Eros e terminar pelo Logos jurídico.

Compreender é relacionar as cousas. Assim, inicialmente, relacionaremos o direito com o amor, e depois, o direito com o espírito, para lograrmos uma visão do conjunto do fenômeno jurídico, nos seus mais diferentes aspectos. Neste procedimento pedagógico, o aluno gradativamente passará da compreensão afetiva para a compreensão racional do direito.

Nihil, difficile amanti, pregava Cícero. Esta verdade aplica-se também ao direito. $O$ seu estudo não é dificil para quem o ama, porque o amor confere aos objetos amados valor, importância, sentido e grandeza. Quem ama, compreende. A compreensão é simpatia, amizade, afinidade, receptividade, penetração e domínio. $O$ ser desejado, pertença a qualquer esfera da cognoscibilidade, é querido pelo Eros e penetrado pelo Logos. A compreensão jurídica necessita da conjugação daqueles dois elementos. Um traz alegria, entusiasmo e dedicação; o outro representa a inteligência, agudeza e profundidade.

Temos aí os fundamentos de uma pedagogia do amor, que orientará as nossas concepções e respeito de uma pedagogia jurídica. $\mathrm{O}$ amor facilita a compreensão do direito, desenvolveo, fá-lo crescer e vitaliza a sua essência. Por isso nunca se louvará demasiado as virtudes do sentimento amoroso. 
$\mathrm{O}$ direito e o amor mantêm íntimas relações entre si. $\mathrm{O}$ direito, afirmou Francesco Carnelutti, é uma das formas que toma o amor para atuar entre os homens. "E a unidade do mundo chama-se amor. $O$ amor une as estrêlas do céu como os homens da terra, para que possam formar a ordem do mundo. Se o sol fica imóvel e a terra gira ao seu redor, a razão disso é a mesma pela qual a mariposa revoluteia sôbre as flôres do jardim. 0 mundo é belo e a sua formosura é o sêlo do amor". Nestas condições, o eminente jurista italiano doutrinou: "Enquanto os homens não saibam amar necessitarão de juizo e política para tê-los unidos".

Tais idéias também foram pregadas por Carlos Ferreira Goschel, uma das figuras mais interessantes de juiz do século passado, segundo nos informa Rudolf Stammler: "Todos os esforços de Goschel giravam em tôrno de um ponto central: a incorporação da idéia do amor aos problemas do Direito e da Justiça. Para êle, não existe Direito sem amor. Com um raciocínio um tanto teológico, invoca, em apôio de sua tese, a analogia com a Trindade. Assim como nesta Deus está sôbre nós, com nós e dentro de nós, o caminho do Direito é: obediência, liberdade e amor. A humanidade, composta por uma multidão de pessoas, aparece unida num único ser: Aquí é onde radica o conceito da personalidade, que se dá por igual em todos os indivíduos e os une em direitos e deveres. Por êste caminho de raciocínio chega o nosso escritor à tese de que "o Direito se identifica com o amor".

Não ha dúvida, pois que precisamos amar o direito, para praticar a justiça. Para subsistir, o direito necessita de muito amor. Enquanto o ódio aniquila os valores, o amor dá-lhes nova vida. Sòmente o amor ao direito poderá salvá-lo nesta época, em que se fala de crise, decadência e morte do valor jurídico. Para desenvolver êsse amor, devemos começar já pelo seu ensino nas Faculdades de Direito. Concordamos com as lições contidas na aula inaugural dos cursos da Faculdade Nacional de Direito, proferida êste ano pelo Professor San Tiago Dantas. Diz êle: "Como, porém, iniciar, na atmosfera de crise em que vivemos, um momento de restauração da supremacia da 
cultura jurídica e de confiança no direito como técnica de contrôle do meio social?

Êsse movimento tem de lançar raízes numa revisão da educação jurídica, e é, portanto, como programa de ação, um apêlo à reforma do ensino do direito nas nossas escolas e universidades.

O ponto de onde, a meu ver, devemos partir, nesse exame do ensino que hoje praticamos, é a definição do próprio objetivo da educação jurídica. Quem percorre os programas de ensino das nossas escolas, e sobretudo, quem ouve as aulas que nelas se proferem, sob a forma elegante e indiferente da velha aula- douta coimbrã, vê que o objetivo atual do ensino jurídico é proporcionar aos estudantes o conhecimento sistemático das instituições e normas jurídicas. Poderiamos dizer que o curso jurídico é sem exagêro, um curso dos institutos jurídicos, apresentados sob a forma expositiva de tratado teórico-prático".

Nesta tendência reformadora da educação jurídica nacional, devemos dar a maior importância ao sentido de uma disciplina básica, que inicia o curso. Trata-se da Cadeira de Introdução à Ciência do Direito.

Faremos aquí algumas considerações em tôrno dela.

A maioria dos compêndios existentes a respeito da Cadeira de Introdução à Ciência do Direito, tanto na literatura jurídica nacional como estrangeira, não guardam relação exata entre o título do livro e o seu conteúdo, que às vezes até encerra cousa inteiramente diversa. É que ainda não se precisou bem a esfera cognitiva daquela disciplina, que é lecionada mais ou menos arbitràriamente de acôrdo com o ponto de vista dos seus improvisados professores, tal como aconteceu desde que surgiu nos cursos jurídicos.

Podemos até enumerar três fases no seu desenvolvimento: a enciclopédica a sociológica e cultural.

De início, a denominação que empolga é a de Enciclopédia Jurídica ao invés de Introdução à Ciência do Direito. Os par- 
tidários dessa corrente procuram justificá-la, històricamente, considerando os primeiros ensaios de Enciclopédia Jurídica as Institutas de Gaius e as Institutas de Justiniano. Já no século XVII apareceram obras interessantes no gênero, como a de N. U. Hummius - Encyclopaedia Juris Universi. No século XVIII, por influência de vários filósofos alemães, aquêle método se intensifica e a literatura enciclopédica jurídica torna-se abundante e confusa, principalmente na Alemanha. A evolução da idéia continua até os nossos dias, e de acôrdo com diversos pontos de vista, obras de grande valor são escritas coco a de Filomusi Guelfi, Brugi, Barberise Mancini, Sangiorgi e Fragapane, na Itália; Ahrens, Friedlander, Ihering, Welker, Goldschmidt e Merkel, na Alemanha. E assim poderiamos citar outros nomes significativos de diferentes países.

Mas o método enciclopédico nem sempre produziu os resultados desejados, e foi mesmo tido por certos autores como anticientífico e anti-pedagógico, porque sobrecarregava em excesso o aluno com múltiplos conhecimentos, e dêste modo, não se tornava fácilmente accessível no início do curso, se bem que pretendia, na afirmação de Guelfi e Brugi, partir-se da Enciclopédia como ciência de Introdução para retornar à Enciclopédia como ciência final.

No século XIX, por influência do positivismo, preponderou a fase sociológica, que apresenta evolução muito interessante, pois considera inicialmente o direito como fenômeno social da sociologia geral, para encaminhar-se no sentido da fundação de uma sociologia jurídica.

Como escreve Gurvitch: "Onde se cava um abismo imenso entre categorias jurídicas tradicionais e a realidade jurídica, a sociologia do direito reveste-se de uma vibrante atualidade. É o que acontece em nossa época; porque, na situação atual, as fórmulas jurídicas abstratas denotam ser totalmente incapazes de captar as ondas tumultuosas da vida real do direito, com suas instituições inéditas, imprevistas, emergindo duma espontaneidade elementar. 0 jurista não pode dar mais um passo sem fazer trabalho de socióligo, sem apelar para a sociologia do direito. $\mathrm{E}$ desde que esta última, como disciplina me- 
todológica, é muitas vezes estranha à educação jurídica, e jamais ocupou a posição que lhe competiria, vemos aquí e alí o despojar de uma sociologia espontânea do direito, abrolhando, ora no trabalho dos juristas teóricos, ora no dos juízes".

$\mathrm{Na}$ época atual, a fase que começa a dominar é a cultural. 0 direito é um fenômeno de cultura, uma realidade histórica e vital. Assim, seguindo os ensinamentos de Windelband e Rickert, a ciência jurídica é uma ciência cultural, e como tal existe um tipo de conhecimento diferente do que formam as ciências da natureza. 0 direito constitui-se como ciencia cultural compreensiva e teleológica.

Neste apanhado geral, claro está, não pretendemos sistematisar tôdas as doutrinas existentes. Queremos apenas salientar uma diretriz evolutiva que se está impondo. Por isso é mistér as grandes linhas do tema, sem entrar em particularidades, que exigem outras considerações para a sua exata compreensão. Aquí aspiramos que a Introdução à Ciência do Direito sirva ao aluno tanto para a compreensão do direito privado como do direito público.

Atendendo a êsses fatos é que apresentamos um programa, inteiramente baseado no programa e nas lições do prof. Hermes Lima, que, nas sucessivas edições do seu livro "INTRODUÇÃO À CIENCIA DO DIREITO”, tem procurado melhorá-lo e aperfeiçoá-lo cada vez mais.

Em primeiro lugar, por razões pedagógicas e metodológicas, admitindo como introito certas considerações preliminares, tão belo programa poderia ser divido em sete partes, do seguinte modo:

Considerações preliminares.

PRIMEIRA PARTE - Introdução à Ciência do Direito pròpriamente dita;

SEGUNDA PARTE - Introdução à Enciclopédia Jurídica ;

TERCEIRA PARTE - Introdução à Lei;

QUARTA PARTE - Introdução à História do Direito; 
QUINTA PARTE - Introdução à Sociologia Jurídica;

SEXTA PARTE - Introdução ao Estado;

SÉTIMA PARTE - Introdução à Filosofia do Direito.

De acôrdo com êsse plano, acrescido aquí e alí de novos capítulos, o programa seria assim:

\section{CONSIDERAÇõES PRELIMINARES}

I. A vocação jurídica. 0 papel do advogado, do juiz e do jurista na justiça.

II. A Pedagogia Jurídica. 0 ensino vivo e animado do Direito. A cultura geral no estudo do direito.

III. A cultura necessária à formação do jurista. A missão da cultura jurídica na época presente. A grandeza do direito.

PRIMEIRA PARTE

INTRODUÇÃO À CIENCIA DO DIREITO PRÓPRIAMENTE DITO

1. A Ciência do Direito. A Ciência do Direito é uma ciência natural ou uma ciência cultural?

2. O objeto da Ciência do Direito. $\mathrm{O}$ fato e o valor jurídico.

A norma.

3. O método jurídico. A diferença entre explicação causal e a compreensão do sentido. A conduta e a experiência na esfera jurídica.

4. O conceito de norma. A norma primária e a norma secundária. A lógica do ser e a lógica do dever ser.

5. A sociedade humana e a sua natureza. Genese e conceito do mundo cultural. Valores sociais e normas de conduta.

6. A palavra direito. Idéia do direito. 0 lícito e o ilícito no direito. A ordem jurídica. Dever jurídico.

7. Direito positivo. Direito positivo e a sociedade. Direito positivo e a autoridade pública. Direito positivo e a coação. 
8. Direito consuetudinário. Evolução do costume. Valor e prova do costume.

9. A elaboração do direito. 0 método jurídico e os seus meios materiais e intelectuais. Papel e classificação dêsses meios. Presunções e ficções.

10. Relações jurídicas: conceito e classificação. Atos jurídicos: conceito, divisão, defeitos, forma, prova, nulidade e modalidade. Representação.

11. Ato ilícito. Responsabliidade civil. Delito civil e delito penal. Abuso do direito.

12. Exercício, defesa e extinção dos direitos.

13. Direito público e privado. Direito geral e particular. Direito comum e especial. Direito regular e singular. Privilégio. 14. Relações entre moral e direito. Causas sociais da distinção entre normas morais e jurídicas. Características das regras morais.

15. Direito subjetivo e o seu conceito. Posição de Duguit e Kelsen. Teorias sôbre a natureza do direito subjetivo. Elementos do direito subjetivo. Direito subjetivo e faculdade jurídica. Direito subjetivo, qualidade e posição jurídicas.

16. Pessoa natural. Pessoa jurídica: conceito e divisão. Objeto do direito.

\section{SEGUNDA PARTE \\ INTRODUÇÃO À INCICLOPEDIA JURIDICA}

17. A importância da enciclopédia jurídica na formação do jurista. Os perigos da especialização e do enciclopedismo. A visão do conjunto como necessária à cultura jurídica.

18. Direito civil, família e casamento. A propriedade. Conceito e evolução.

19. Direito comercial. Significação histórica do comércio. Evolução do direito comercial.

20. Direito do trabalho. Conceito. Desenvolvimento histórico. A legislação brasileira do trabalho. 
21. Direito internacional público. Histórico e problemas.

22. Conceito, evolução e fontes do Direito Constitucional.

Conceito de Constituição.

23. Direito administrativo. Domínio. Conceito.

24. Direito Penal. Conceito. Problemas.

25. Direito judiciário. Aspecto prático e aspecto teórico.

\section{TERCEIRA PARTE \\ INTRODUÇÃO À LEI}

26. O conceito de lei. A lei através dos tempos. A lei como fonte do direito. A lei e as fontes materiais e formais do direito.

27. Natureza imperativa da lei jurídica. Significação das doutrinas sôbre a lei. Lei e vontade social.

28. Formação da lei. Lei jurídica e lei científica. Leis coercitivas e dispositivas. Normas rígidas e elásticas. Leis quanto ao conteúdo e quanto à sanção. Lei e Regulamento.

29. Obrigatoriedade da lei. Aplicação da lei. Hierarquia e constitucionalidade das leis.

30. Revogação da lei. Esbôço histórico da noção de retroatividade. Teorias sôbre a retroatividade. Aplicações da regra.

31. Interpretação da lei. Espécies de interpretação. Métodos e resultados da interpretação. Trabalhos preparatórios. Analogia. Princípios gerais do direito.

32. Direito internacional privado. Natureza de suas normas. Princípios reguladores.

33. Revelação científica do direito. Lacunas no direito.

34. A doutrina e a jurisprudência.

35. Codificação das leis. Recepção de direito estrangeiro.

36. Conceito de Justiça. Relações do direito com a justiça. Equidade e o seu conceito. 


\section{QUARTA PARTE \\ INTRODUÇÃO À HISTORIA DO DIREITO}

37. O direito e as condições adequadas no espaço social, para o seu aparecimento. Pontos de vista sôbre êsse problema. Evolução do direito primitivo. Responsabilidade, culpa, processo, juramento e formalismo no direito antigo.

38. O direito positivo na Grécia. Roma e o desenvolvimento do direito.

39. A Idade Média e a organização do direito. 0 fenômeno da recepção.

40. Notas sôbre a evolução do direito positivo brasileiro. 0 período republicano. As Constituições.

\section{QUINTA PARTE}

\section{INTRODUÇÃO À SOCIOLOGIA JURÍDICA}

41 Evolução sociológica do direito. Características do direita primitivo. Vingança privłada, responsabilidade coletiva e culpa no direito primitivo.

42 O processo e o formalismo no direito primitivo.

43. Contribuição da sociologia ao estudo do direito.

44. Contribuição da Antropologia e Psicologia ao estudo do direito.

45. Direito e Ordem Social. O direito como instrumento de transformação social. 0 direito como elemento de conservação social.

46. As diversas correntes da Sociologia Jurídica.

SEXTA PARTE

\section{INTRODUÇÃO AO ESTADO}

47. A noção do Estado. Evolução histórica do conceito de Estado. Definição. 
48. O poder político e as suas origens. Teorias teológicas e jurídicas. O Contrato Social. Teorias sociológicas.

49. Natureza social do Estado.

50. Condições da existência do Estado. Estado e Nação. A base territorial do Estado. $\mathrm{O}$ vínculo político.

51. Formas de Estado e formas de govêrno. Autocracia, Oligarquia e Democracia. A representação política. Monarquia e República. Governo presidencial e govêrno parlamentar.

52. História e evolução do conceito de soberania. No mundo romano, na Idade Média e nos tempos modernos.

53. O problema da liberdade do Estado.

\section{SÉTIMA PARTE}

\section{INTRODUÇÃO À FILOSOFIA DO DIREITO}

54. Direito Natural e o seu conceito. Na Grécia. Em Roma. Na Idade Média. A Escola de Grotius. Observações sôbre a concepção do direito natural.

55. A teoria racional de Kant.

56. O direito na concepção filosófica de Hegel.

57. A Escola Histórica.

58. A teoria do fim do direito: Ihering.

58. A teoria da solidariedade social: Duguit.

60. A teoria pura do direito: Kelsen.

61. Relações entre Direito e Economia. A interpretação materialista da história. A Doutrina de Stammler.

Parece que o plano exposto não carece de maiores demonstrações. Êle ordena sistemáticamente tôda a matéria contida no mencionado programa e apresenta-a de modo pedagógico e metodológico, a fim de facilitar aos alunos a compreensão e assimilação dos diversos assuntos que integram a disciplina. Justifica-se a inclusão dos capítulos novos porque se articulam perfeitamente com o resto, numa sequência natural. Um programa de Introdução à Ciência do Direito exige que se trate 
com especial ênfase do conceito de Ciência do Direito. E cumpre definir-lhe bem a sua natureza, depois das aquisições modernas do pensamento jurídico. Muito embora êsse fato pareça evidente, não conhecemos nenhum compêndio da especialidade que cuide diretamente dêsse delicado ponto. A maioria dos autores esquece que deve expor lições sôbre a Introdução à Ciência do Direito. E cousa paradoxal. Basta consultar os programas das Faculdades de Direito do país, para verificar-se que os expositores fogem, na maioria dos casos, inteiramente daquilo que devia constituir a sua especialidade. Os pontos tratam de direito civil, filosofia do direito e outras matérias, mas não desenvolvem o conteúdo própro da Ciência do Direito.

Nesse terreno, cumpre fazer justiça ao ilustre e culto jurista Hermes Lima, professor catedrático de Introdução à Ciência do Direito na Faculdade de Direito da Universidade do Brasil, que escreveu, de acôrdo com as suas conviç̧ões, uma verdadeira Introdução à Ciência do Direito, magnifico livro já em sétima edição.

Em livros de igual natureza, escritos aquí e lá fora, nenhum como o seu trata da matéria específica com tanto acêrto e ujsteza. A sua Introdução à Ciência do Direito fica rigorosamente dentro do seu objeto próprio. Não se perde em teorias, invadindo a esfera da Filosofia do Direito, como em geral acontece com a maioria dos tratados. Não. É, realmente, um trabalho introdutório, com tôda modéstia que o título implica. Fixa noções. Precisa conceitos. Expõe doutrinas com sobriedade e nos seus princípios fundamentais. Assim orienta e esclarece, e não se demora em discussõoes, o que ficaria fora inteiramente do programa. É um livro prático e efiicente, que põe o aluno diretamente em contato com o nosso direito positivo, obrigando-o desde logo a conhecer a nossa legislação vigente.

Tendo em consideração a honrosa exceção exposta, a verdade é que a cadeira de Introdução à Ciência do Direito no Brasil ainda não logrou precisar o seu conteúdo específico, porque, ou ela foi lecionada por professores improvisados, que 
nada sabiam sôbre a matéria, e então, não podiam fixar a sua esfera própria, ou ela foi lecionada por civilistas, penalistas e outros especialistas do direito. Ora, é sabido que o especialista, quando sai do seu terreno é petulante e procede desastradamente em outros setores, não se convencendo da sua ignorância no assunto. E foi assim que a Cadeira de Introdução à Ciência do Direito, regida por aquêles especialistas, tomou, de acốrdo com os casos, um sabor civilista, penalista, comercialista ou constitucionalista, sempre dentro de um critério unilateral.

Tais especialistas não podiam compreender de forma alguma que também a Cadeira de Introdução à Ciência do Direito é uma especialidade, e como tal tem caracteres próprios. Por isso o professor de Introdução à Ciência do Direito deve ser um especialista no seu setor, um especialista sim, mas de muita cultura geral. $\mathrm{O}$ civilista, o comercialista, e mesmo o internacionalista, se chegarem a lecionar aquela Cadeira, por certo, quasi sempre serão máus professores. $\mathrm{E}$ a experiência tem confirmado a justeza dessa afirmação.

Dividimos o programa em sete partes, para realçar a importância das matérias nele tratadas. Os alunos necessitam, especialmente no início do curso, de noções claras, bem definidas e delimitadas, para poderem desenvolver o raciocínio jurídico.

O direito, a visão enciclopédica jurídica, a lei, o Estado, a História, a Sociologia do Dierito e as escolas jurídicas são os temas centrais da Cadeira e constituem assuntos de verdadeira introdução na especialidade. Nesta seriação ordenada e sistemática, a compreensão do direito tornar-se-á mais fácil, agradável, sugestiva e empolgante.

Eis os benefícios daquêle fecundo programa, em que o aluno vai gradativamente adquirindo novas idéias no suceder dos pontos e aprendendo a relacioná-las num todo uno e orgânico, a fim de alargar cada vez mais a sua visão do direito, para entendê-lo na sua plenitude. Depois dessa fase preliminar está em condições de aprofundar o direito, ou na especializa- 
ção de um ramo qualquer, ou na meditação dos seus problemas fundamentais dentro de pesquisas filosóficas. 0 fato é que 0 aluno, neste procedimento, sente viver em si o direito, que vai gradualmente formando a sua mentalidade específica.

Assim a nossa preocupação magna consiste em tornar o direito interessante e atraente, principalmente aos jovens estudantes. Para isso cumpre ministrar-lhes um sabor mais cultural do que profissional, discordamos daquêles que pensam que as faculdades de direito só devem fornecer um ensino prático e de mero interêsse imediato. Esse critério formaria men tes limitadas, sem nenhuma visão das cousas. Nestas instituições de ensino superior, não se trata de preparar simplesmente advogados hábeis e magistrados competentes, mas, sobretudo, homens de cultura de nível universitário, capazes de compreender a época e o mundo atual. Do contrário, teremos bacharéis mediocres, leguleiz juízes escravisados ao texto das leis, sem saber interpretá-las com o verdadeiro espírito de justiça.

Goethe, já no seu tempo, criticava aquela orientação meramente pragmatista, sem vida nem entusiasmo, com o objetivo de formar advogados militantes. Daí inclinar-se mais para 0 estudo de medicina. Nas suas magistrais memórias, escreve esta página que merece ser lida e refletida por todos os professores de direito:

"O meu repetidor, depois de haver tido por algum tempo paciência com as divagações dos meus discursos, fez-me compreender, por fim, que devia ter, em primeiro lugar, em conta o meu propósito imediato, que era o de examinar-me, doutorar-me e logo exercer. E para isto não há que buscar as cousas em remotas distâncias. Não se pergunta como e quando nasceu uma lei, qual foi o motivo interno e externo da sua promulgação; não se trata de saber até que ponto a modificaram 0 tempo e o costume, ou se acaso uma interpretação equivocada ou uma jurisprudência desencaminhada a aplicaram ao revés. Estas investigações são bôas para os eruditos que a elas consagram a sua vida; porém nós nos limitamos ao que atual- 
mente rege, e o fixamos em nossa memória de modo que o tenhamos presente sempre para servir-nos disso em proveito e defesa dos nossos clientes. Desta maneira fica apetrechada a juventude para as necessidades da vida imediata, e o resto virá na medida do seu talento e da sua atividade. Entregou-me em seguida os seus cadernos de perguntas e respostas, com as quais podia examinar-me logo, porque recordava bastante bem o pequeno catecismo jurídico de Hopps; o resto supri-o com aplicação e pronto estive em condições de apresentar-me a exame.

Porém se dêste modo perdi tôda atividade própria no estudo, pois eu não tinha interêsse por nada positivo, e queria explicar-me tudo, se não segundo a razão, històricamente ao menos, em troca achei um campo mais vasto onde exercitar as minhas fôrças, que utilizei do modo mais singular, cedendo a um interêsse que me vinha de fora.

A maior parte dos meus comensais eram médicos. Como é sabido, são êstes os únicos estudiosos que falam com calor da sua ciência, da sua profissão, fora das horas de classe. Isto está na natureza mesma da sua profissão. Os fins dos seus esforços são os mais sensíveis, e ao mesmo tempo os mais altos, os mais simples e os mais complicados. A medicina ocupa ao homem inteiro, porque ao homem inteiro se aplica. Quando o rapaz aprende nela refere-se a uma prática importante, certamente perigosa, porém em vários sentidos compensadora. Portanto, aplica-se com paixão a inteirar-se do que há que saber e fazer, em parte porque lhe interessa por si mesmo, em parte porque lhe oferece a alegre perspectiva de independência e bem-estar".

0 curso de direito pode perfeitamente despertar idêntico entusiasmo. Mas para isto exige professores que saibam lecionar a matéria. Quando isto acontece, empolga a juventude. No Brasisil, felizmente, temos exemplos expressivos a registrar nesse sentido. Releiamos esta curiosa página do grande escritor Graça Aranha, relatando-nos com vida e alma o famoso concurso de Tobias Barreto: 
"O que êle dizia era novo, profundo, sugestivo. Abria uma nova época na inteligência brasileira e nós recolhiamos a nova semente: sem saber como ela frutificaria em nossos espíritos, mas seguros que por ela nos transformavamos. Êsses debates incomparáveis eram pontuados pelas contínuas ovações que faziamos ao grande revelador. Nada continha o nosso entusiasmo. A Congregação humilhada em seu espírito reacionário, curvava-se ao ardor da mocidade impetuosa. Prosseguíamos impávidos, certos de que, conduzidos por Tobias Barreto, estávamos emancipando a mentalidade brasileira, afundada na teologia, no direito natural, em todos os abismos do conservantismo. Para mim, era tudo isto delírio. Era a alucinação de um estado inverossímel que eu desejava, adivinhava, mas cuja realização me parecia sobrenatural. Tobias Barreto fez a sua prova de preleção oral. $O$ orador atingiu para minha sensibilidade ao auge da eloquência. Quando terminou, recebeu a mais grandiosa manifestação dos estudantes, a cujo entusiasmo aderiram os lentes unânimes. Foi então que, tomado de um impulso irreprimível, saltei a grade e por entre as aclamações dos estudantes e diante do assombro da Congregação, atirei-me aos braços de Tobias Barreto, que me recolheu comovido e generoso. Já é acadêmico? perguntou-me, admirado da minha pouca idade. "Sim, calouro". Abraçou-me novamente. "Pois bem, vá à minha casa esta noite". Que deslumbramento! Não voltei aos meus colegas. Fiquei ali mesmo, metido em algum canto da sala da Congregação e saí acompanhando, como uma pequenina sombra, o Mestre. À noite, eu estava em sua casa em Afogados. Nunca mais me separei intelectualmente de Tobias Barreto.

São passados mais de quarenta anos dêsse grande choque mental, e ainda ressinto em mim as suas inefáveis vibrações. Por êle me fiz homem livre. Por êle saí dos nevoeiros de uma falsa compreensão do universo e da vida. Por êle afirmei a minha personalidade independente e soberana. A lição de Tobias Barreto foi a de pensar desassombradamente, a de pensar com audácia, a de pensar por si mesmo, emancipado das autoridades e dos cânones. A sua primacial ação foi destrutiva. Na- 
turalmente. No Brasil há sempre muito que destruir. Mas ao mesmo tempo que a sua crítica destruia, novas perspectivas surgiam para a cultura, novas bases para a inteligência se firmavam. Para se avaliar o que foi a ação de Tobias Barreto, basta atender o que eram os estudos de direito antes dêle e depois dêle. Saiamos da disciplina de Braz Florentino, de Ribas, de Justino, para as lições de tantos mestres emancipados. O Código Civil Brasileiro, construção de Clovis Bevilaqua, se filia à inspiração de Tobias. A crítica se renova por êle. Silvio Romero, Araripe e o próprio José Veríssimo são seus discípulos. A nossa mesquinha filosofia, o que tem de mais inteligente, vem da libertação do grande mestre do pensamento livre. Ainda hoje se pode dizer como se disse de Kant, que voltar a Tobias é progredir.

Poderíamos ainda citar muitos mestres do direito, que no Brasil produziram idêntico efeito. Basta-nos aqui, porém, provar que os cursos de direito podem suscitar vivo ardor e entusiasmo na alma dos estudantes, despertando-lhes vigorosamente a vocação jurídica.

No sentido de esclarecer a vocação do aluno, o professor logo de início deve mostrar, de forma bem acessível e expressiva, o papel do advogado, do juiz e do jurista na justiça.

O estudo da Psicologia do Jurista tem alto interêsse não só pedagógico, vocacional e profissional, como mesmo cultural, pois visa explicar o complexo fenômeno da consciência do Direito nas suas expressões pessoais.

O assunto, porém, não é dificil, e com êsse critério, foi pouco versado. Por isso mesmo tratamo-lo com especial atenção, e oportunamente desejamos dar maior desenvolvimento às nossas conclusões fundamentais.

Nesta oportunidade, limitar-nos-emos a fazer rápidas considerações sôbre a rica personalidade do jurista, sem nos determos mais demoradamente no exame das suas formas particulares de legislador, juiz ou advogado, para só mencionar aquêles que têm como profissão o Direito. Concordamos com esta observação caracteriologica de Sternberg: 
“A profissão do jurista é de tal natureza que nela as faculdades adquiridas (erudição e rotina prática) sós não servem de nada, é antes uma profissão de personalidade, semelhante à do artista, do mestre, do sacerdote e do militar. Estas profissões distinguem-se de tôdas as demais em que tem sumo interêsse o que sejam os seus representantes como homens, enquanto tal questão é bastante indiferente, por exemplo, a respeito do construtor de uma máquina a vapor".

Renato Treves, que acentua, nos seus estudos, o caráter complexo e multiforme do Direito, achando que o seu conceito só pode ser examinado amplamente na Filosofia da Cultura, observa também com muita justeza o seguinte: "Esta profunda vinculação, quasi diria esta identificação, do direito com distintos setores da vida espiritual que resulta da análise da estrutura objetiva do direito, é ademais plenamente confirmada pela análise do aspecto vital, subjetivo do mesmo. 0 direito, sob êste aspecto, com efeitoo, não pode incluir-se em nenhum dos tipos ideais básicos do homem teorético, estético, econômico, político, etc., porque o tipo do homem jurídico vincula-se sempre a uma vontade supra individual, coletiva e normativa, especialmente porque tem uma estrutura complexa mesclada com distintas atividades espirituais. Segundo Sprenger, a estrutura vital do direito manifesta-se em duas formas: um essencialmente político e outro que se aproxima da teorética, mas não coincide de todo com esta pela vinculação, que tem com o espírito coletivo. À primeira forma (a política), corresponde-lhe o tipo que reclama direitos para si e busca o poder nas normas jurídicas socialmente dadas, e corresponde-lhe também o típo passivo do político. À segunda forma (predominante teorética) corresponde-lhe o tipo que vive sobretudo pela idéia da justiça e que "não se sente simplesmente como parte de uma sociedade jurídica, mas como o seu expoente e por ela responsável"; corresponde-lhe o tipo que é bastante próximo ao teorético, ao fundador de princípios, porém, como dissemos, não se identifica com êste porque a legitimidade teórica e a validade universàl e a consequência lógica, neste caso, aplicam-se sòmente ao jugo recíproco das esferas sociais do poder". 
Examinemos assim o papel do jurista.

Êsse nosso mundo conturbado precisa muitíssimo do jurista, porque necessita da ordem, da disciplina e da organização, do direito e da justiça.

Mas o jurista, para cumprir a sua missão, não pode ser apenas um técnico, um profissional, um especialista que não sai da sua esfera específica, no exame dos textos legais de um determinado ramo jurídico. Não. 0 jurista deve ser um homem que pensa, medita e reflete e possue cultura geral; que conhece o seu meio, a sociedade e os problemas da época.

São os juristas vrdadeiros que podem reabilitar o papel do direito e evidenciar a sua grandeza e missão no mundo.

Para alcançar êsse resultado, o jurista deve estar à altura dos tempos. Um jurista ignorante, desatualizado, que ficou com o passado, não tem nenhuma importância e não influi em coisa alguma. Não pode participar da vida trepidante contemporânea. $O$ que êle necessita, acima de tudo, é de cultura, muita cultura; sim, de cultura para desenvolver, fazer crescer e valorizar o jurídico, porque o direito sem cultivo, permanece uma entidade fora do complexo cultural.

Os juristas devem cultivar o direito, mas com as técnicas modernas, com os recursos da ciência atual e com as luzes da filosofia - tudo para se ter um direito que acompanhe o evolver da civilização.

Nestas condições, o jurista deve adquirir cultura universitária e, para ter uma imagem objetiva do mundo e da vida, estudar a Física, a Biologia e a Sociologia nas suas concepções atuais. São essas ciências, que, com o auxílio da Filosofia, constroem a cultura moderna.

$O$ verdadeiro jurista deve aprimorar a sua cultura universitária. Não estará, ao contrário, à altura da sua missão, à altura dos tempos, à altura das suas grandes responsabilidades.

0 direito atual está exigindo cientistas do direito, investigadores objetivos dos processos jurídicos, sociólogos especializados, técnicos legislantes, juízes de personalidade, e não me- 
ros leguleios, exegrtas, hermeneutas, homens da lei no sentido antigo. 0 jurista deve saber elaborar a lei científicamente, interpretá-la dentro de critérios lógicos e aplicá-la com o mesmo rigor metodológico. Assim o direito sai do terreno do arbitrário e artificial e entra na esfera da certeza e da precisão.

Dentro dêsse ponto de vista, o jurista adquirirá uma mentalidade copernicana, isto é, uma mentalidade internacional e mundial e nunca uma mentalidade ptolomaica, nacionalista e regionalista, como ainda hoje acontece.

Daí o primado do direito internacional. Hoje a paz é o problema básico aa nossa época, e da sua solução depende a solução de todo e qualquer outro problema. Por isso pregamos a universalidade do direito, que, agora, não pode mais ficar circunscrito a um círculo social, porque lhe cumpre abranger com as suas normas o mundo inteiro.

Mas não fiquemos nestas belas generalizações e majestosas concepções abstratas. Se o termo jurista designa o homem que tem como profissão o direito, realmente, o jurista é o homem da Ágora e do Fôro, e por isso mesmo deve conhecer e agir. A ciência jurídica é teleológica e possue uma finalidade prática.

Desta maneira, diante da confusão do mundo moderno, o jurista não pode ficar de braços cruzados. Deve agir e agir com muita intensidade, para fazer triunfar o direito. Como escreveu Ripert: "A obra do jurista é a única que fica quando o tumulto das revoluções se aplaca".

Como se pode verificar por esta rápida síntese, a tese é fecunda, e constitui mesmo rico manancial de novas teses.

Não é um estudo isolado, mas sólido conjunto de meditações e experiências, que formam um todo maravilhoso.

Eis o meio de imprimir aos estudos jurídicos do Brasil um movimento criador, e quebrar com a inércia, rotina e estagnação, agitando idéias, pregando novas doutrinas e sacudindo a mentalidade jurídica estática com o dinamismo de um programa de vastas realizações. 
Nesta época trágica, de lutas, revoluções e guerras, quando só se fala em crise, declínio, decadência e morte do direito, é preciso doutrinar a grandeza do direito, para restabelecer o seu precioso valor no seio da cultura.

$\mathrm{E}$ todo verdadeiro jurista deve fazer vigoroso exame de consciência para se conhecer a si próprio e assim assumir conscientemente as altas responsabilidades do seu importante mistér.

A existência daquêle entusiasmo, porém, depende muito do professor. A êste cumpre-lhe formar o espírito do novo jurista. Mais valioso do que transmitir conhecimento é penetrar na alma do aluno, para lhe despertar as energias íntimas e fortificar a vocação. Não nos cansamos de repetir. 0 que, realmente, importa é a correta formação do jurista. "Mais importante que todos os preceitos, ensinava Savigny, é o espírito e a formação dos juristas". Não se trata de fazer especialistas herméticos, técnicos do direito, escravisados aos textos legais, sem visão dos problemas humanos. Não. 0 jurista verdadeiro deve ter uma formação cultural de base sociológica e filosófica. A sociologia é a raiz do direito, que planta a árvore jurídica na sociedade; a filosofia representa-se pelas folhas da árvore, que alimentam e renovam o direito através da atmosféra da justiça. Mas o direito não é uma cousa, um objeto, um instrumento, simples técnica. É algo superior, ideal, nobre e elevado. Tal direito merece fervoroso culto, respeito e veneração do jovem que o estuda.

Neste terreno, o professor de direito tem papel decisivo, e como tal deve ser educador, mestre, uma personalidade modelar. Uma pessoa só erudita e possuidora de cultura livresca não basta, porque, carece de autoridade, e não desperta nos alunos o entusiasmo. Por isso é recomendável que o professor seja ou tenha sido bom advogado, juiz ou legislador. $O$ direito como profissão constitui ativdade eminentemente prática. $\mathrm{O}$ profissional impõe respeito, quando conhece bem a sua profissão por tê-la exercido com amor e dedicação.

O professor é um exemplo, e assim goza de autoridade, respeito e consideração. Mas não lhe basta ser sábio, erudito e 
homem profundamente bem informado. Não. Acima de tudo deve ser amigo da juventude, simpático e estimulador, para despertar vocações, desenvolver o amor do direito na alma dos discípulos. O bom professor é um mago. Encanta, arrebate, atrai e seduz. É como Sócrates - um sedutor. Assim exerce influência definitiva e jamais será olvidado.

São professores desta estirpe que moldam a alma das novas gerações.

No presente estudo, tôdas as nossas teses têm um sentido pedagógico, vocacional e metodológico; um sentido, na verdade, teleológico e cultural. Imprimimos tal significação aos nossos trabalhos jurídicos, em virtude da grande experiência adquirida na prátiza do magistério. Durante muito tempo ensinamos, com o maior prazer, a crianças, depois fomos professor do ensino secundário; agora, desde há alguns anos, exercemos o magistério superior com amor e dedicação, e, por isso, êsse nosso entusiasmo pelo bem lecionar, levou-nos à radiosa concepção da aula como verdadeira obra de arte. Ela requer, na realidade, que o professor seja, ao mesmo tempo, artista da palavra e da pena, dos gestos e dos métodos, da ciêricia e da filosofia, para vivificar as lições e tornar as preleções interessantes. Exige dêle, ainảa, que não abuse das abstrações, pois, elas isoladas, não comovem o espírito juvenil, mas precisam, para nele produzir efeito, ser completadas por imagens, metáforas, exemplos sugestivos, casos concretos, etc.

0 magistério para nós, dêste modo, tem encantos inefáveis. Pensamos que o professor que não vibra em contato com os seus alunos, com as inteligências moças, com as almas jovens, não nasceu para esta sagrada carreira, mesmo porque um mestre sem entusiasmo não pode ser compreendido pela mocidade.

A aula autêntica tem, pois, que se tornar ambiente de simpatia e afinidade, atmosfeha espiritual de compreensão e inteligência, de estudo e meditação, um meio, enfim, agradável e aprazível, cheio de significação, onde todos tiram proveito e colhem algo de novo. 
Ao professo: cumpre-lhe, porém, impregnar-se da sua missão nobilíssima de formar espíritos, fecundar idéias e despertar a inteligibilidade. Dentro da şala de aula sente-se alegre, feliz e satisfeito, com a alma confortada. Faz-lhe bem o convívio com os seus alunos, aos quais, por simpatia e amizade, passa a amar como se filhos seus fôssem, guardando depois para sempre, com profunda emoção e saudade, a lembrança dêsses amiguinhos.

Êsses fatos é que impressionam vivamente a alma dos alunos, que assim adquirem amor aos mestres e respeito pela casa em que formaram o espírito. Neste ambiente favorável processa-se a educação pela palavra cheia de autoridade do professor. A sua orientação, estímulos, conselhos, exemplos de fortaleza, riqueza de ensinamentos, tudo constituirá lembrança indelével, causando posteriormente no sêr dos alunos as mais doces emoções, e quando homens de responsabilidade, sempre se recordarão com vivo prazer da vida escolar, tão grata e cheia de acontecimentos agradáveis.

As palavras dos mestres educam. Socrates, que soube falar ao gênero humano, ainda hoje, é ouvido com maior respeito. O verbo de Cristo, pela mesma razão, cada dia se atualiza mais, e sem dúvida nenhuma, à proporção que os anos passarem, penetrará mais profundamente na consciência da humanidade...

As palavras de fé e verdade vivem... e nunca jamais morrem. Através delas é que a educação transmite e perpetua, de geração para geração, em todos os séculos, os tesouros da cultura.

De acôrdo com tais convicções, sempre lecionamos a Introdução à Ciência do Direito. Esta Cadeira é, sem dúvida alguma, a principal do curso. Assim exige muito do professor. Não só erudição e cultura como experiência e prática profissional. Nesta Cadeira, o professor deve ser o exemplo do verdadeiro jurista. Quando isto acontece, os alunos ganham muitíssimo pela fôrça do exemolo, pelo magnetismo pessoal, pela irradiação de uma personalidade atuante. 
O professor aquí tem uma missão especial, infelizmente, ainda pouco compreendida. Daí a existência de máus professores que perturbam a vocação dos alunos, ensinando-lhes coisas indigestas de um direito artificialmente complicado e dificil. Não sabem de como começar o estudo jurídico, objeto específico daquêla disciplina. Por isso os seus programas são verdadeiras colchas de retalhos, um todo inorgânico e caótico.

Já é tempo de cuidar dessa Cadeira com rigor científico, isto é, com rigor pedagógico ,metológico e cultural. Eis o que nos propomos.

Nesta disciplina, o valor do professor não está tanto na erudição e informação como na arte de ensinar com método, ordem, técnica, sistema, ciência e filosofia.

Urge facilitar a compreensão do direito, estimulá-la e desenvolvê-la. Eis a atitude criadora e realmente fecunda. Nestas condições, sente-se o aluno enlevado e tem a alegria de pesquisar, para encontrar as verdades por si mesmo. Sobrevemlhe dêsse procedimento a confiança em si próprio. $O$ estudo do direito torna-se uma maravilha, um encanto. $O$ aluno, então, aplica-se com ardor e entusiasmo crescente nas matérias do seu curso.

Neste programa, tôda a matéria está tão intimamente relacionada e segue um desenvolvimento gradativo e ordenado, que pode, realmente, oferecer magnífica visão do universo jurídico.

Sim. O Direito, a Enciclopédia Jurídica, o Estado, a Lei e as Escolas Jurídicas entrelaçam-se num todo sistemático de implicação recíproca. Por isso é impossível conceber-se o Direito sem relacioná-lo com o Estado, de vez que o Estado possui um elemento essencial à sua essência, isto é, a coação, a fôrça atuante no campo jurídico, para assegurar o cumprimento e a eficácia das normas. Igualmente não se pode imaginar o Estado sem pensar no Direito, pois, é o Dierito que justifica a razão de ser do Estado, limitando-lhe a esfera de abrangência através da Lei. Esta, como ato do Estado, emanada do Poder Legislativo, de acôrdo com a forma prescrita na Constituição, regula tôda a atividade jurídica nos mais diferentes setores. 
Tem oportunidade aí a Enciclopédia Jurídica, que nos proporciona agradável e proveitosa viagem espiritual às mais variadas regiões do mundo jurídico. Com êsses materiais colhidos nestas diferentes disciplinas, podemos proveitosamente analisar as grandes Escolas Jurídicas e tomar contato com os maic. res juristas de todos os tempos.

Eis aí, ao nosso ver, justificação satisfatória do programa exposto, que garante a plena compreensão do direito.

Dentro dessa orientação, a Cadeira de Introdução à Ciência do Direito visa a uma cultura jurídica extensiva, pois, aos jovens, em função da idade, a assimilação de tôda classe de matérias enriquece-ihe o espírito. "O homem maduro, escreveu Keyserling, aspira a aprofundar e potenciar o sêr pelos mesmos motivos que, nos anos de juventude, impulsionam-lhe a dilatá-lo e enriquecê-lo". A filosofai constitui ocupação própria para os homens experientes.

Nestas condições, no início do estudo de direito, importa a visão do conjunto, idéias gerais, alargamento da experiência e a percepção das relações do todo. 0 pensamento jurídico deve começar com essas intuições e conceitos largos e amplos. Depois dêsse esfôrço cabe a cultura intensiva. Nesse proceder ajustado, podemos adquirir uma cultura jurídica completa.

A mencionada Cadeira deve desenvolver no espírito do aluno o apetite jurídico, o desejo de conhecer o mundo do direito, através de intuições, revestidas de simpatia e amor. Em seguida, necessita precisar-lhe os conceitos jurídicos. Aquí temos já uma fase de lógica, de raciocínio e meditação, que exige clareza, precisão e exatidão.

A ciência do direito deve firmar e definir os conceitos jurídicos, como à filosofia de direito he compete discutí-los e ampliá-los. 0 conceito é aquilo que o espírito concebe, gera e cria. Mas aquí significa a captação plena de algo nos seus elementos determinantes e universais. Como ensina Ortega Y Gasset: "Sem o conceito, não saberíamos bem onde começa nem onde acaba uma cousa; isto é, as cousas como impressões são fugazes, fugidias, vão-se-nos de entre as mãos, não as possuímos. Ao 
atar o conceito umas com outras, fixa-as e nô-las entrega prisioneiras. Platão diz que as impressões nos escapam se não as ligamos com a razão, como, segundo a lenda, as estátuas de Demetrios fugiam noturnamente dos jardins se não se as atava.

Jamais nos dará o conceito o que nos dá a impressão, a saber: a carne das coisas. Porém isto não obedece a uma insuficiência do conceito, sendo a que o conceito não pretende tal ofício. Jamais no dará a impressão o que nos dá o conceito, a saber: a forma, o sentido físico e moral das cousas.

De sorte que, se devolvemos à palavra percepção o seu valor etimológico, onde se alude a colher, apresar - o conceito será o verdadeiro instrumento ou órgão da percepção e apresamento das cousas.

Exgota, pois, a sua missão e a sua essência, com ser, não uma nova causa, mas um órgão ou aparato para a posse das cousas".

Assim a Cadeira de Introdução à Ciência do Direito é uma Cadeira de preparação científica e cultural. Não adianta aqui a especialização. Ela pode ser até prejudicial ao aluno, nesta fase da sua formação. $O$ que mais interessa são os princípios, noções gerais, idéias, visão panorâmica, para a segura orientação posterior técnico-profissional. Uma vez criado o interêsse, despertada a curiosidade, manifestado o desejo de maiores conhecimentos, estudante poderá, por conta própria, aprofundar o que aprendeu. Esta independência já lhe proporciona muito prazer, alegria e satisfação.

Êsse programa afirma uma orientação, uma diretriz, uma doutrina jurídica, que sustenta o seguinte: a compreensão do direito vitaliza e espiritualiza o valor jurídico. Ela constitui um fator de grandeza, e não há dúvida que a intuição do grandioso eleva. "O grande pelo tamanho não possui necessáriamente grandeza, disse Keyserling: para que algo tenha grandeza é preciso que provoque uma correspondente exaltação do sentimento pessoal; e esta exaltação depende por sua vez de condições individuais. Assim o aluno desde cêdo deve sentir a beleza e a magnitude da carreira que abraçou". 
Neste assunto, Roma deu-nos a lição definitiva, exprimindo admiràvelmente a grandeza do direito: Jus est rerum divinarum atque humanarum notitia, justi atque injusti scientia. Por isso não basta ensinar ao futuro jurista o direito romano. Muito mais importante é ministrar-lhe o conhecimento das virtudes romanas, como a fôrça de vontade, o caráter, a constância e a tenacidade, a decisão, a iniciativa, capacidade de ação e trabalho. $\mathrm{O}$ direito deve ser uma escola de virtudes. $\mathrm{O}$ que fez a grandeza de Roma pode agora também fazer a grandeza de um povo.

Por todos êsses fatos, o direito romano é imortal, sendo o único da história cuja evolução pode ser acompanhado num período de mais de mil anos através de fases de grandeza e decadência na vida agitada da humanidade. Ihering escreveu: "O Direito romano conduziu-me frequentes vezes muito acima do meu próprio horizonte e revelou-me idéias de verdade universal".

Convém, aliás, que o estudante desde já compreenda que o direito romano e o direito anglo-saxônico são os dois sistemas jurídicos fundamentais da civilização ocidental. Dentro dessa orientação, cumpre apresentar uma idéia ampla, rica e sempre muito receptiva do direito, reagindo contra a unilateralidade, a visão parcial, o ponto de vista hermético do fenômeno. "O problenna último, ensina Whitehead, é conceber um fato completo". Por isso o direito também exige um espírito aberto, relacionando-se com o indivíduo e a sociedade, assuntos que constituem objeto respectivamente da Psicologia e da Sociologia jurídicas. Vincula-se, porém, mais estreitamente com a vida e a cultura. Com a vida através dos usos, costumes, conduta e a história; com a cultura, por intermédio de todos os valores culturais, desde a economia até a ética e religião. E assim que o direito firma o pé na realidade e alça a cabeça nas alturas do ideal.

Nunca é demais pregar a grandeza do direito. Ela estâ na ordem, na liberdade, na disciplina do indivíduo e na organização da sociedade. Mas o direito fàcilmente pode desviar-se dêsse caminho, e comprometer a sua magnitude, pela anarquia, 
desordem, servilismo e desmoralização, ficando preso a interêsses pessoais, mesquinhos e pequenos; como pode cristalizar-se em formas rígidas, e dominado pela rotina, não renovarse.

Em virtude dos fatos apontados, sustentamos um direito ascendente, dinâmico e universal. Sim. Um direito ascendente contra a decadência social; um direito dinâmico contra as fôrças retrógadas do meio; um direito aberto e universal contra uma sociedade hermética e nacionalista. Sempre que o direito não acompanha a evolução social, necessàriamente decai.

Ninguém ignora que a grandeza do direito está na paz, na ordem social, na harmonia das classes, na tranquilidade do povo, no bem-estar da humanidade. E tal grandeza constitui a aspiração máxima de todo jurista. Ela tem, aliás, rigorosas bases científicas e filosóficas.

O fenômeno jurídico é um fenômeno social. Como tal, complexo e dos mais complexos, atendendo à hierarquia científica que, em gráu crescente de amplitude, vai da matemática à sociologia. Mas esta complexidade reduz-se a uma série de aspectos particulares, de caráter estático e dinâmico, no plano real e valorativo. $\mathrm{O}$ direito é grande nas suas dimensões físicas e na sua valorização espiritual.

Justifica-se, pois, plenamente a razão por que o jurista tudo vê através do direito, que possui larga perspectiva sôbre tôdas aś cousas, podendo constituir verdadeiro sistema de compreensão da realidade. 0 direito, principalmente para 0 jurista, é sempre o critério de apreciação universal. E nesse conjunto de relações, aumenta o seu prestígio, ocupando papel de importância na ordem das cousas.

Nesta condições, convém acentuar claramente, que negar o direito é negar um aspecto fundamental da cultura, e afirmar os valores anti-jurídicos, contidos na predominância da fôrça, da violência, da arbitrariedade, da insegurança e falta de garantia; é pregar abertamente a animalidade, a selvageria, os elementos instintivos e irracionais, os métodos cruéis e máus. 0 direito, nunca o esqueçamos, ao contrário, é racional, volitivo e muito humano. 
Nesta época trágica, marcada pelos acontecimentos de brutal ferocidade, que abalou profundamente os alicerces da civilização, nesta época de lutas, revoluções e guerras, quando, por motivos muito justificados, só se fala em crise, declínio e morte do direito, é preciso doutrinar a grandeza do direito, para restabelecer o seu valor, com as regras obrigatórias tanto para os indivíduos como para as nações.

Infelizmente ainda vivemos numa fase geocêntrica do direito, em que preponderam os estados nacionais. Continuamos, apesar de todos os progressos da ciência, com uma visão ptolomaica e unilateral do jurídico. 0 direito, dentro de tal concepção arcaica, é impotente para resolver os problemas da época. Para solucioná-los satisfatóriamente, necessitamos partir do heliocentrismo jurídico, de uma concepção jurídica copernicana.

Precisamos, realmente, de um direito universal, mundial, um direito para tôda a comunidade humana. Êsse direito, de ampla perspectiva e largos horizontes, vai revogar e revisar todos os conceitos jurídicos tradicionais. $\mathrm{O}$ fim do direito é a paz. $\mathrm{E}$ a paz consegue-se pelo triunfo da justiça. Mas êsse direito deve ter por base a soberania mundial e não a soberania nacional. Eis a lição de Roma, que já foi esquecida, mas precisa, agora, ser lembrada e praticada.

Só a visão copernicana do direito, entretanto, garante a paz. Os problemas magnos da época devem ser examinados no plano mundial.

Nestas condições, o direito básico já não é o direito civil, mas o direito internacional. 0 primado está com êle na reconstrução do mundo.

Tal concepção do direito modificará os conceitos de sociedade, democracia e liberdade. Dentro dêsse critério, certas noções fechadas, estreitas e limitadas serão rompidas definitivamente. Teremos uma nova idéia das cousas, e por isso mesmo, uma nova mentalidade jurídica.

Eis a razão por que escrevemos a presente tese. 0 direito precisa acompanhar a evolução da ciência, estar à altura da época e incorporar, no seu sistema, os progressos da cultura. 
Dentro do critério exposto, procuramos compreender 0 direito nos seus problemas e respectivas soluções, chegando naturalmente a determinadas conclusões pedagógicas, científicas, filosóficas, técnicas e culturais. Assim, no desenvolvimento dêsse estudo, sustentamos os seguintes pontos de vista:

1. ${ }^{\circ}$. A Cadeira de Introdução à Ciência do Direito é uma disciplina autônoma, cuja esfera própria, constituída de várias matérias, precisa ser exatamente definida, cumprindo, entretanto, jamais confundí-la com a Filosofia do Direito, Teoria Geral do Direito, Enciclopédia Jurídica, História do Direito, Epistemologia Jurídica ou outro qualquer ramo do direito, como frequentemente acontece, o que é facil de se verificar no exame dos programas existentes e livros publicados sôbre o assunto. Origina-se tal confusão por falta de disciplina mental e cnhecimento profundo do sentido pedagógico, vocacional e profissional da Cadeira. É êrro, pois, transformá-la numa ciência universal, numa cosmologia jurídica, que jamais poderá ser assimilada pelos alunos nessa fase inicial do curso. Por isso é preciso rigor na diferenciação e especificação do seu conteúdo, determinando os seus métodos próprios e idôneos, a fim de evitar transgressões de limites do seu campo essencialmente introdutório e compreensivo. Dêsse procedimento advirão grandes benefícios para o ensino jurídico.

2. ${ }^{\circ} \mathrm{O}$ estudo do direito deve ser feito metòdicamente. A Cadeira de Introdução à Ciência do Direito visa auxiliar a compreensão do direito. Por isso encerra mais cultura extensiva que cultura intensiva, desejando ministrar idéias do conjunto e visão panorâmica da realidade jurídica. Quer fixar noções, precisar conceitos e alimentar idéias jurídicas. É uma cadeira que deve fazer o aluno pensar na lei, sentir a justiça e querer a realização do direito. Ela tem um sentido pedagógico, vocacional e cultural.

O direito, realmente, é uma esfera especializada, altamente complexa e técnica. Para a sua compreensão, há necessidade 
de iniciação. Para o iniciado aquí tudo é especial, diferente e novo. Essa iniciação deve ser metódica, organizada e bem dirigida. Precisamos começar pela noção de direito e avançar até as mais elevadas concepções de justiça, sempre mostrando de como o direito pode ser estudado científicamente, sem nunca esquecer que aquela Cadeira é de Introdução à Ciência do Direito.

$3 .^{\circ}$ Defendemos uma nova concepção do direito, afastada tanto do formalismo como do anti-formalismo. Procurando superar êsses pontos de vista, relacionamos o direito com a vida e a cultura. Assim vitalizamos o direito, pondo-o em contato com as realidades sociais e o cultivamos, aperfeiçoando-o com os valores cuturais até o mais alto gráu possível de espiritualização. Não olvidamos, entretanto, que o jurista deve ser o homem da Ágora e do Fôro e por isso mesmo lhe cumpre participar ativamente da vida social. Damos exemplos do que doutrinamos. Desde longo tempo, temos doutrinado pacientemente uma série de idéias que gradativamente estão impressionando o nosso meio cultural, tais como o Ministério Público como instrumento da salvação nacional, a Universidade do Trabalho como entidade capaz de mudar a mentalidade do povo brasileiro, o Culto da Grandeza como um culto que pode despertar as energias da Nação e criar uma elite consciente e criadora, enfim, a União de Civis e Militares, porque unidos farão grandes cousas em benefício do Brasil. Todos êsses assuntos foram objetos de diversas publicações, artigos de jornais e livros.

4. ${ }^{\circ}$ A Ciência do Direito é, ao mesmo tempo, uma ciência natural, cultural e normativa, porque o direito, na sua realidade, implica o fato, o valor e a norma. Assim, a natureza da cinêcia jurídica é complexa e abrange aquêles três fatores. A norma é uma síntese do fato e do valor, concretizada num imperativo. Dentro dêsse critério, a ciência do direito investiga o seu objeto numa realidade histórica e vital. A ciência do direito assim se classifica essencialmente como ciência cultural e teleológica.

$5 .^{\circ}$ Aqui a nossa preocupação é a compreensão do direito. Esta denominação já é bastante expressiva, para significar 
a orientação nova seguida, salientando, para os entendedores do assunto, cuidar mais da compreensão do que da explicação do direito. Na verdade, esforça-se por conciliar no direito a ciência natural com a ciência cultural. Eis aí o aspecto original do tema, que é integrador dos esforços científicos em diversos campos da pesquisa ,adotando por isso mesmo uma concepção cultural.

A compreensão do direito doutrinada encerra uma atitude realista, valorativa e axiológica, ao lado de uma atitude histórica, sociológica e vital. Pensamos que com tal orientação, o direito poderá tomar grande impulso no seu desenvolvimento, polarizado com os principais valores, porque, dêste modo, a cultura é posta ao seu serviço, para, em seguida, colocar o direito em defesa da civilização. 